\title{
Infrequent mutation of the tumour-suppressor gene Smad4 in early-stage colorectal cancer
}

\author{
C Mamot', G Mild ${ }^{2}$, J Reuter ${ }^{2}$, U Laffer ${ }^{3}$, U Metzger ${ }^{3}$, L Terracciano ${ }^{4}$, J-L Boulay ${ }^{2}$, R Herrmann ${ }^{1,2}$ \\ and C Rochlitz*,1,2 \\ 'Division of Oncology, University Hospital Basel, 403 I Basel, Switzerland; '2Department of Research, University Hospital Basel, 403I Basel, Switzerland; \\ ${ }^{3}$ The Swiss Group for Clinical Cancer Research (SAKK), 3000 Bern, Switzerland; ${ }^{4}$ Institute of Pathology, University Hospital Basel, \\ 403 I Basel, Switzerland
}

\begin{abstract}
Smad4 is a candidate tumour-suppressor gene identified recently on chromosome 18q2।.1. Both alleles are inactivated in nearly onehalf of pancreatic carcinomas, but its role in the tumorigenesis of other tumours is still unknown. The aim of this study was to investigate the potential involvement of the Smad4 locus in early-stage colorectal cancers (stages I-III) in tumour samples from a randomised multicentre trial. Of a large collection of DNA samples, 73 with a loss of one allele of the Smad4 gene were analysed for the presence of point mutations in the remaining gene. Patients, from whom biopsies were isolated, were part of a previous randomised multicentre study of the Swiss Group for Clinical Cancer Research on the benefit of adjuvant chemotherapy (SAKK study 40/8I). Mutation analysis was restricted to the highly conserved C-terminal domain (exons 8, 9, I0 and II) of Smad4, using PCR and single-strand conformational variant analysis. Two of the 73 patients (3\%) with loss of one allele of Smad4 had a point mutation in the remaining allele. These results indicate that whereas Smad4 point mautations are prevalent in pancreatic carcinoma, they are infrequent in early stages (I-III) of colorectal cancer.
\end{abstract}

British Journal of Cancer (2003) 88, 420-423. doi:I0.I038/sj.bjc.6600733 www.bjcancer.com

(C) 2003 Cancer Research UK

Keywords: DPC4; loss of heterozygosity (LOH); Smad4; TGF $\beta$; tumorigenesis

Deletion of a chromosomal region is a frequent cytogenetic alteration observed in carcinogenesis. The loss of tumour-suppressor genes has been reported in numerous types of human tumours, in particular those of the gastrointestinal tract (Vogelstein et al, 1988). APC and p53 have been widely recognised as important tumour-suppressor genes inactivated during colorectal carcinogenesis. Several other tumour-suppressor genes have been located on chromosomes 1p, 8p, 18q and 22q. In particular, loss of heterozygosity $(\mathrm{LOH})$ at $18 \mathrm{q} 21$ is correlated with carcinomas of the colon, and other tumours such as pancreatic carcinoma, renal cell carcinoma, melanoma and breast carcinoma (Schutte et al, 1996; Barbera et al, 2000). Much of the interest in this region arose because reports indicated that $18 \mathrm{q}$ losses are associated with high metastatic potential and reduced patient survival (Iino et al, 1994).

In fact, several potentially cancer-related genes map to the $18 \mathrm{q} 21$ region, including bcl-2, gastrin-releasing peptide gene and cellular homologue of yes-1. However, none of these have been observed to be mutated in colorectal cancer (CRC). Fearon et al. (1990) identified another tumour-suppressor gene localised on 18q21, designated DCC for deleted in colorectal cancer. However, there have been several cases in which loss of expression did not correlate with LOH (Kikuchi-Yanoshita et al, 1992), and mutation in the coding region of the DCC gene has been infrequently

*Correspondence: Professor C Rochlitz, Division of Oncology, University Hospital Basel, Petersgraben 4, CH-403I Basel, Switzerland;

E-mail: crochlitz@uhbs.ch

Revised 2I October 2002; accepted 7 November 2002 detected (Cho et al, 1994; Sato et al, 2001). Owing to the controversial evidence as to the role of DCC in cancer, additional genetic analysis of the $18 \mathrm{q} 21$ region led to the identification of other potential tumour-suppressor genes, including three candidate tumour-suppressor genes: Smad2, Smad4 and Smad7. These genes are involved in signal transduction of the TGF $\beta$ signalling pathway. Members of the transforming growth factor (TGF)- $\beta$ family transmit their signals from the plasma membrane to the nucleus through combinations of serine/threonine kinase receptors and their downstream effectors, known as Smads. After the Smad4 (MADH4) gene was isolated from the same region as a tumour-suppressor gene for pancreatic cancer (Hahn et al, 1996), mutation analysis of this gene has been carried out in various cancers. In recent studies, Smad4 was identified as a genetic target in pancreatic carcinomas, inactivated through homozygous deletion $(n=5)$, intragenic mutation $(n=3)$ and lack of protein $(n=2)$ in 10 out of 16 pancreatic cell lines (Barbera et al, 2000). Furthermore, it could be shown that when genetically inactivated this tumour-suppressor in the TGF $\beta$ signalling pathway represents a prognostic factor in invasive pancreatic cancer influenced by Smad4 status (Tascilar et al, 2001). In addition to observations in pancreatic carcinomas, Smad4 is also known as a gene involved in juvenile polyposis tumour predisposition syndrome (Howe et al, 1998; Huang et al, 2000). Mutations of the Smad4 gene have been detected in some colorectal cancers, but its role in this specific cancer remains unclear. The frequencies of mutations $(5-45 \%)$ have been found to be low (Takagi et al, 1996; MacGrogan et al, 1997; Ohtaki et al, 2001), but data originated from relatively small studies, and the tumour populations examined were inhomogeneous explaining the broad range of incidences found. 
The aim of this study was to further expand these data by Smad4 mutation analysis of a large set of early-stage (I-III) colorectal cancer patients treated in a randomised multicentre trial of 5-fluorouracil (5-FU)/Mitomycin C adjuvant chemotherapy of the Swiss Group for Clinical Cancer Research (SAKK study 40/81). Owing to the significance of $\mathrm{LOH}$ in colorectal cancer and the role of the remaining gene, this study was focused on patients with an allelic loss of one Smad4.

\section{METHODS}

\section{Patients}

Patients from whom biopsies were isolated, were part of a previous randomised multicentre study of the SAKK on the benefit of treatment with adjuvant chemotherapy between 1981 and 1987 (Laffer, 1995). Deoxyribo nucleic acid (DNA) samples of these patients were extracted from tumour as well as from healthy tissue derived from the same patient in order to perform genetic analyses. Paraffin-embedded material was available from 329 of the 505 patients. To investigate genetic alterations in the $18 \mathrm{q} 21$ region in these tumours, a gene dosage study of the tumour-suppressor genes Smad2, Smad4 and DCC was performed (Boulay et al, 1999). For technical reasons, high-quality DNA for analysis was available from 294 patients only. Individual dosage of the Smad4 gene showed a total deletion frequency (one or both alleles) of $68 \%$ when compared to normal tissue. In total, 167 patients $(=57 \%)$ were detected with an allelic loss of one Smad4 copy. In this study, we randomly chose 73 of these 167 patients to search for the presence of point mutations in the remaining gene. After analysis of these 73 out of 167 patients, two point mutations of Smad4 had been detected, and for statistical reasons, further mutation analysis in the remaining 94 out of 167 patients did not seem necessary to substantiate our finding.

\section{Gene copy status scoring}

Genomic samples from 294 patients were tested for copy dosage of the Smad4 gene using TaqMan quantitative real-time PCR (PerkinElmer, Huenenberg, Switzerland). Copy status of the Smad4 gene was determined by comparing tumour DNA to DNA from normal tissue derived from the same patient as described previously (Boulay et al, 1999).

\section{Duplex PCR}

Polymerase chain reaction (PCR) amplification on DNA was performed in $15 \mu \mathrm{l}$ reaction volume, containing $1.5 \mu \mathrm{l} 10 \times \mathrm{PCR}$ buffer (Perkin-Elmer, Huenenberg, Switzerland), $10 \mathrm{mM}$ 2'desoxyribonucleosoid-5'-triphosphate (dNTPs), $20 \mu \mathrm{M}$ of each primer, $1 \mathrm{U}$ of AmpliTaq Gold (Perkin-Elmer, Huenenberg, Switzerland), ${ }^{32} \mathrm{P}$ Oligo $(2.5 \mu \mathrm{l} 10 \times$ Buffer, $20 \mu \mathrm{M}$ forward primer,
$1 \mu \mathrm{l}$ PNK and $1 \mu \mathrm{l} \gamma^{32} \mathrm{P}$-adenosine triphosphate (ATP) incubated $30 \mathrm{~min}$ at $37^{\circ} \mathrm{C}$ ) and $100 \mathrm{ng}$ DNA. Duplex PCR for Smad4 gene was done using primers EX 8/1 and EX 8/2, EX 9/1 and EX 9/2, EX 10/1 and EX 10/2, and finally EX $11 / 1$ and EX $11 / 2$ (Table 1). Polymerase chain reaction conditions were as follows: 40 amplification cycles of denaturation at $94^{\circ} \mathrm{C}$ for $45 \mathrm{~s}$, annealing at $55^{\circ} \mathrm{C}$ for $60 \mathrm{~s}$, and extension at $72^{\circ} \mathrm{C}$ for $60 \mathrm{~s}$, followed by one cycle at $72^{\circ} \mathrm{C}$ for $10 \mathrm{~min}$. Amplification products were loaded on a $0.4 \mathrm{~mm}$ acrylamide gel in a 'Model S2 Sequencing Gel Electrophoresis Apparatus (Life Technologies, Switzerland)'. Electrophoresis settings are: $1800 \mathrm{~V}, 35-40 \mathrm{~mA}, 60 \mathrm{VA}$ and $120 \mathrm{~min}$. Polymerase chain reactions without DNA templates were performed as negative controls. Bands were subsequently cut out from the single-strand conformation polymorphism (SSCP)-gel and reamplified in a PCR.

\section{Sequencing analysis}

Reamplification of DNA was performed in a $50 \mu$ l reaction volume, containing $5 \mu \mathrm{l} 10 \times$ PCR buffer (Perkin-Elmer, Huenenberg, Switzerland), $10 \mathrm{~mm}$ dNTPs, $20 \mu \mathrm{M}$ forward and backward primer, $1 \mathrm{U}$ of AmpliTaq Gold (Perkin-Elmer, Huenenberg, Switzerland) and $38 \mu \mathrm{l} \mathrm{H} \mathrm{H}_{2} \mathrm{O}$. PCR conditions were as follows: 35 amplification cycles of denaturation at $94^{\circ} \mathrm{C}$ for $45 \mathrm{~s}$, annealing at $55^{\circ} \mathrm{C}$ for $60 \mathrm{~s}$ and extension at $72^{\circ} \mathrm{C}$ for $60 \mathrm{~s}$, followed by one cycle at $72^{\circ} \mathrm{C}$ for $10 \mathrm{~min}$. Sequencing analysis was performed by Microsynth (Basel, Switzerland) on a fluorescence-based DNA sequencer that utilises capillary electrophoresis with 96 capillaries operating in parallel.

\section{RESULTS}

Among the 294 tumours for which gene dosage data (Smad2, Smad4 and DCC) were available, 167 tumours (57\%) showed heterozygous loss of Smad4 (Boulay et al, 1999), and 73 out of 167 samples were randomly chosen for mutation analysis. Of these, only two (3\%) carried point mutations in Smad4 in tumour but not the corresponding healthy tissue, as demonstrated by PCR-SSCP (Figure 1). The two mutations were located in the highly conserved C-terminal Smad4 homology region. One confirmed point mutation was found in exon 9 and another point mutation in exon 11. Both mutations were confirmed by direct sequencing analysis showing one mutation resulting in an amino-acid change from arginine to serine; the second mutation led to an exchange of alanine to valine (Table 2).

However, a caveat in the interpretation of our data needs to be mentioned: informative and reproducible data were available from a total of 174 complete exons $(8,9,10$ and 11$)$ derived from the 73 defined patients. This shortcoming of our data was because of technical problems in the analysis, caused by the sometimes poor quality of the DNA, as is often observed with nucleic acids isolated from paraffin-embedded tissue. Nevertheless, since the exons for which interpretable results were available were equally distributed

Table I Primer-sequences designed for duplex-PCR

\begin{tabular}{|c|c|c|}
\hline Primer & Forward & Reverse \\
\hline EX 8/I & 5'-GAAAGCCTTATATC ТТТСТC-3' & 5'CACGTATCCATCAACAGTAA-3' \\
\hline $\mathrm{EX} 8 / 2$ & 5'-TCCTTCAAGCTGCССTATTG-3' & 5'-CAATTIITAAAGTAACTATCTGA-3' \\
\hline $\mathrm{EX} 9 / 1$ & 5'-TATTAAGCATGCTATACAATCTG-3' & $5^{\prime}$-GTGGTCACTAAGGCACCTGA-3' \\
\hline $\mathrm{E} \times 9 / 2$ & 5'-TAAAGGTGAAGGTGATGTTT-3' & 5'-CAAATAGAGCTTTAAGTCTA-3' \\
\hline EX $10 / 1$ & 5'-GTCAGGCATTGGTITTTAATG-3' & 5'-ATCCTGGGCCAGGGATGTTT-3' \\
\hline EX $10 / 2$ & 5'-AAACATCCCTGGCCCAGGAT-3' & 5'-CAAAAATGTCATCATCCC AGT-3' \\
\hline $\mathrm{EX} \mid 1 / 1$ & 5'-AAGAGATCACССTGTCССТСТ-3' & 5'-CCAGCAAGGTGTTTCTाTGA-3' \\
\hline $\mathrm{EX} \mid 1 / 2$ & 5'-GGATTACCCAAGACAGAGCA-3' & 5'-GTATTITGTAGTCCACC ATC-3' \\
\hline
\end{tabular}




\section{2}

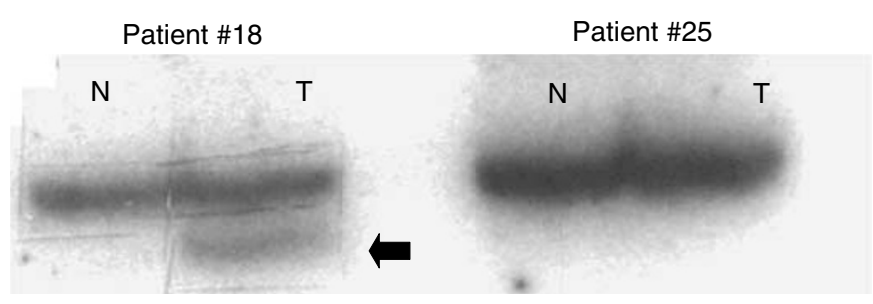

Figure I SSCP analysis of Smad4 in early-stage colorectal cancer. Representative results of PCR-SSCP analysis using EX9/2f and EX9/2r primers (exon 9). Patient No. 18 shows a migration alteration in tumour DNA (T) compared to normal tissue DNA (N) defined as an SSCP, whereas patient No. 25 does not display any polymorphism. Extra bands ( PCR before subjected to sequencing analysis.

Table 2 Mutations of Smad4 gene detected in colorectal cancer

\begin{tabular}{ccll}
\hline Patient & Exon & Alteration & Effect \\
\hline 18 & 9 & AGA $\rightarrow$ AGC & Arginine $(R) \rightarrow$ Serine $(S)$ \\
376 & 11 & GC $\underline{T} \rightarrow G_{-}$ & Alanine $(A) \rightarrow$ Valine $(V)$ \\
\hline
\end{tabular}

Two out of 73 patients (3\%) with point mutations of Smad4.

between the eight different amplicons we used in our study, our conclusion of a very low frequency of Smad4 point mutations in the population studied is not put into question by this technical shortcoming.

\section{DISCUSSION}

Smad proteins are a novel family of proteins that function downstream of serine/threonine kinase receptors to transduce signals for members of the TGF $\beta$ superfamily (Massague, 1996). The three Smads (Smad2, Smad4 and Smad7) encoded in the $18 \mathrm{q} 21$ chromosomal region participate in the signalling mechanisms subsequent to TGF $\beta$-receptor complex formation. Smad4, a co-Smad of Smad2, is known as a tumour-suppressor gene in different cancer types. Tumour-suppressor genes are often inactivated when one allele acquires a mutation and the second allele is lost, typically through deletion (Cavenee et al, 1983). The tumour-suppressor gene p53 represents just one example for this classic concept (Miller et al, 1992), while for another tumoursuppressor gene, DCC, these findings could not be confirmed (Sato et al, 2001). Our screen of 73 patients with early-stage colorectal cancer (I-III) carrying a loss of one Smad4 allele identified two mutations of the remaining allele (3\%), a finding that is in accordance with results described in the literature (Schutte et al, 1996; Miyaki et al, 1999).

Mutation analysis was restricted to exons 8, 9, 10 and 11 of Smad4, which together span the entire conserved C-terminal Smad4 homology region. Since $90 \%$ of the Smad4 mutations reported are located in that highly conserved region, the number of undetected mutations is expected to be low when the analysis is restricted to these mutation hot spots (Hahn et al, 1996; Takagi et al, 1996; Kong et al, 1997). The low rate of point mutations detected by our method deserves further comments: SSCP has been shown to be a highly sensitive method to identify mutations in PCR-generated fragments. The sensitivity of SSCP analysis is widely disputed in the literature, with reports ranging from $35 \%$ (Sarkar et al, 1992) to nearly 100\% (Orita et al, 1989). Of course, certain mutations may not be detected using this method. Furthermore, it is possible that some of our tumours had large intragenetic deletions of Smad4, which would have been missed with the detection method used. However, the single factor having the greatest effect on SSCP sensitivity is the size of the DNA fragments. An optimal size of 200 base pairs (bp) or less was used in our study (160-180 bp), which is described as the most sensitive for single-base substitutions (Sheffield et al, 1993).

Among the mediators of TGF $\beta$ signalling encoded by the $18 \mathrm{q} 21$ chromosomal region, two were identified as involved in activating TGF $\beta$ signalling: Smad 2 and Smad4, and one, in the inhibition of TGF $\beta$ signalling: Smad7. Thus, one could have expected that inactivation of Smad 4 might result in a TGF $\beta$ resistance that would favour tumour expansion. Interestingly, the patients with deletion of Smad4 did not show a significantly worse prognosis than those without a deletion (Boulay et al, 2002). In contrast, in the same population, Smad4 seemed to be a predictive marker for 5FU/ mitomycin adjuvant chemotherapy. However, whether Smad4 plays a key role in tumorigenesis of colorectal cancer is still unclear.

To date, a significant number of Smad4 point mutations have been found only in pancreatic carcinomas (50-60\%), biliary tract carcinomas (15\%) or colorectal carcinomas (5-20\%) (Hahn et al, 1996; Schutte et al, 1996; MacGrogan et al, 1997). Although the existence of additional unknown target tumour-suppressor genes in the region of $18 \mathrm{q} 21$ cannot be ruled out, recently published results strongly suggest a significant contribution of Smad4 gene inactivation in advanced tumour stages. Metastatic colorectal carcinomas including carcinomas metastasised to the liver showed a considerably higher frequency $(31-35 \%)$ than invasive carcinomas without distant metastasis (7\%) (Miyaki et al, 1999; Ohtaki et al, 2001). Our findings of less than $5 \%$ point mutations are at the lower end of the spectrum and confirm the low frequency of point mutations of Smad4 in early-stage colorectal cancer without distant metastasis. The limitation to patients with loss of one Smad4 allele-initially used to select a population with a presumably high mutation frequency-is one possible theoretical explanation for our findings. However, in pancreatic and biliary tract carcinomas, patients with $\mathrm{LOH}$ represent a group with an especially high point mutation frequency in the remaining gene, making this explanation highly unlikely (Hahn et al, 1998; Barbera et al, 2000).

Other possible explanations for the absence of Smad4 point mutations in colorectal cancer at this stage include methylation changes at the promoter and alternative splicing or changes in mRNA stability (Roth et al, 2000). The importance of genes that undergo alterations at low prevalence, however, may as yet be underestimated. Such events may contribute significantly to the genetic variety within a tumour type and, thus, to the complexity of human tumorigenesis. Since it is likely that many alterations of low prevalence exist in human cancers, an individual tumour might still acquire several of these different alterations with a high probability, making low prevalence alterations a powerful driving force of the carcinogenic process.

In conclusion, our findings indicate that Smad4 point mutations are infrequent in early stages of colorectal cancer. However, it cannot be completely ruled out that inactivation of Smad 4 could be a common genetic event at later stages of colorectal cancer. Future research comparing early and advanced stages is required to investigate the tumour-suppressor pathway in colorectal cancer and to redefine the role Smad4 signalling plays in tumorigenesis.

\section{ACKNOWLEDGEMENTS}

This work was supported by a grant from the Swiss Cancer League and Cancer League, Basel. 


\section{REFERENCES}

Barbera VM, Martin M, Marinoso L, Munne A, Carrato A, Real FX, Fabre M (2000) The 18q21 region in colorectal and pancreatic cancer: independent loss of DCC and DPC4 expression. Biochim Biophys Acta 1502: 283 296

Boulay JL, Mild G, Lowy A, Reuter J, Lagrange M, Terracciano L, Laffer U, Herrmann R, Rochlitz C (2002) SMAD4 is a predictive marker for 5fluorouracil-based chemotherapy in patients with colorectal cancer. $\mathrm{Br} \mathrm{J}$ Cancer 87: $630-634$

Boulay JL, Reuter J, Ritschard R, Terracciano L, Herrmann R, Rochlitz C (1999) Gene dosage by quantitative PCR. Biotechniques 27: 228-230, 232

Cavenee WK, Dryja TP, Phillips RA, Benedict WF, Godbout R, Gallie BL, Murphree AL, Strong LC, White RL (1983) Expression of recessive alleles by chromosomal mechanisms in retinoblastoma. Nature 305: $779-784$

Cho KR, Oliner JD, Simons JW, Hedrick L, Fearon ER, Preisinger AC, Hedge P, Silverman GA, Vogelstein B (1994) The DCC gene: structural analysis and mutations in colorectal carcinomas. Genomics 19: $525-531$

Fearon ER, Cho KR, Nigro JM, Kern SE, Simons JW, Ruppert JM, Hamilton SR, Preisinger AC, Thomas G, Kinzler KW et al (1990) Identification of a chromosome $18 \mathrm{q}$ gene that is altered in colorectal cancers. Science 247: $49-56$

Hahn SA, Bartsch D, Schroers A, Galehdari H, Becker M, Ramaswamy A, Schwarte-Waldhoff I, Maschek H, Schmiegel W (1998) Mutations of the DPC4/Smad4 gene in biliary tract carcinoma. Cancer Res 58: 1124-1126

Hahn SA, Schutte M, Hoque AT, Moskaluk CA, da Costa LT, Rozenblum E, Weinstein CL, Fischer A, Yeo CJ, Hruban RH, Kern SE (1996) DPC4, a candidate tumor suppressor gene at human chromosome 18q21.1. Science 271: 350-353

Howe JR, Roth S, Ringold JC, Summers RW, Jarvinen HJ, Sistonen P, Tomlinson IP, Houlston RS, Bevan S, Mitros FA, Stone EM, Aaltonen LA (1998) Mutations in the SMAD4/DPC4 gene in juvenile polyposis. Science 280: $1086-1088$

Huang SC, Chen CR, Lavine JE, Taylor SF, Newbury RO, Pham TT, Ricciardiello L, Carethers JM (2000) Genetic heterogeneity in familial juvenile polyposis. Cancer Res 60: 6882-6885

Iino H, Fukayama M, Maeda Y, Koike M, Mori T, Takahashi T, KikuchiYanoshita R, Miyaki M, Mizuno S, Watanabe S (1994) Molecular genetics for clinical management of colorectal carcinoma. 17p, 18q, and $22 \mathrm{q}$ loss of heterozygosity and decreased DCC expression are correlated with the metastatic potential. Cancer 73: $1324-1331$

Kikuchi-Yanoshita R, Konishi M, Fukunari H, Tanaka K, Miyaki M (1992) Loss of expression of the DCC gene during progression of colorectal carcinomas in familial adenomatous polyposis and non-familial adenomatous polyposis patients. Cancer Res 52: $3801-3803$

Kong XT, Choi SH, Inoue A, Xu F, Chen T, Takita J, Yokota J, Bessho F, Yanagisawa M, Hanada R, Yamamoto K, Hayashi Y (1997) Expression and mutational analysis of the DCC, DPC4, and MADR2/JV18-1 genes in neuroblastoma. Cancer Res 57: $3772-3778$
Laffer U (1995) Long-term results of single course of adjuvant intraportal chemotherapy for colorectal cancer. Swiss Group for Clinical Cancer Research (SAKK). Lancet 345: 349-353

MacGrogan D, Pegram M, Slamon D, Bookstein R (1997) Comparative mutational analysis of DPC4 (Smad4) in prostatic and colorectal carcinomas. Oncogene 15: $1111-1114$

Massague J (1996) TGFbeta signaling: receptors, transducers, and Mad proteins. Cell 28: $947-950$

Miller CW, Simon K, Aslo A, Kok K, Yokota J, Buys CH, Terada M, Koeffler HP (1992) p53 mutations in human lung tumors. Cancer Res 52: $1695-1698$

Miyaki M, Iijima T, Konishi M, Sakai K, Ishii A, Yasuno M, Hishima T, Koike M, Shitara N, Iwama T, Utsunomiya J, Kuroki T, Mori T (1999) Higher frequency of Smad4 gene mutation in human colorectal cancer with distant metastasis. Oncogene 18: $3098-3103$

Ohtaki N, Yamaguchi A, Goi T, Fukaya T, Takeuchi K, Katayama K, Hirose K, Urano T (2001) Somatic alterations of the DPC4 and Madr2 genes in colorectal cancers and relationship to metastasis. Int $J$ Oncol 18: $265-270$

Orita M, Iwahana H, Kanazawa H, Hayashi K, Sekiya T (1989) Detection of polymorphisms of human DNA by gel electrophoresis as singlestrand conformation polymorphisms. Proc Natl Acad Sci USA 86: $2766-2770$

Roth S, Laiho P, Salovaara R, Launonen V, Aaltonen LA (2000) No SMAD4 hypermethylation in colorectal cancer. $\mathrm{Br} J$ Cancer 83: $1015-1019$

Sarkar G, Yoon HS, Sommer SS (1992) Screening for mutations by RNA single-strand conformation polymorphism (rSSCP): comparison with DNA - SSCP. Nucleic Acids Res 20: $871-878$

Sato K, Tamura G, Tsuchiya T, Endoh Y, Usuba O, Kimura W, Motoyama T (2001) Frequent loss of expression without sequence mutations of the DCC gene in primary gastric cancer. Br J Cancer 85: 199-203

Schutte M, Hruban RH, Hedrick L, Cho KR, Nadasdy GM, Weinstein CL, Bova GS, Isaacs WB, Cairns P, Nawroz H, Sidransky D, Casero Jr RA, Meltzer PS, Hahn SA, Kern SE (1996) DPC4 gene in various tumor types. Cancer Res 56: $2527-2530$

Sheffield VC, Beck JS, Kwitek AE, Sandstrom DW, Stone EM (1993) The sensitivity of single-strand conformation polymorphism analysis for the detection of single base substitutions. Genomics 16: 325-332

Takagi Y, Kohmura H, Futamura M, Kida H, Tanemura H, Shimokawa K, Saji S (1996) Somatic alterations of the DPC4 gene in human colorectal cancers in vivo. Gastroenterology 111: 1369-1372

Tascilar M, Skinner HG, Rosty C, Sohn T, Wilentz RE, Offerhaus GJ, Adsay V, Abrams RA, Cameron JL, Kern SE, Yeo CJ, Hruban RH, Goggins M (2001) The SMAD4 protein and prognosis of pancreatic ductal adenocarcinoma. Clin Cancer Res 7: 4115-4121

Vogelstein B, Fearon ER, Hamilton SR, Kern SE, Preisinger AC, Leppert M, Nakamura Y, White R, Smits AM, Bos JL (1988) Genetic alterations during colorectal-tumor development. N Engl J Med 319: 525-532 